Open Access

\title{
The influence of social capital on opportunity emergence and exploitation: a comparison of portfolio and serial entrepreneurs
}

\author{
Christian Lechner $^{1^{*}}$ (D), Florian Kirschenhofer ${ }^{2}$ and Michael Dowling ${ }^{3}$
}

\author{
* Correspondence: \\ christian.lechner@unibz.it \\ 'School of Economics and \\ Management, Free University of \\ Bolzano, Universitätsplatz 1 - piazza \\ Università, 1, Bozen-Bolzano, Italy \\ Full list of author information is \\ available at the end of the article
}

\begin{abstract}
Habitual entrepreneurs are a frequent and important phenomenon in entrepreneurship and for the economy. We lack, however, a systematic understanding of the advantages or disadvantages of multiple business ownership and specifically if portfolio and serial entrepreneurs are different in detecting and exploiting opportunities. Research on habitual entrepreneurs has mainly focused on a human capital and an organizational perspective. In order to further advance our understanding of habitual entrepreneurship, we conducted a case study research focusing on the social capital of habitual entrepreneurs and on how, by investigating differences between serial and portfolio entrepreneurs, it is related to the emergence and exploitation of opportunities.

JEL: L26 - Entrepreneurship
\end{abstract}

\section{Background}

Although opportunity emergence is at the heart of entrepreneurship research, a substantial theoretical fundament remains absent. More in-depth exploration of the phenomenon is thus required (Suddaby et al. 2015). Habitual entrepreneurs present us with an opportunity to study opportunity emergence. According to a widely accepted definition, "habitual founders had established at least one other business prior to the start-up of the current new independent venture" (Birley and Westhead 1993, p. 40). Portfolio entrepreneurs are defined as entrepreneurs who are involved in several projects at the same time (Hall 1995; Westhead et al. 2003) whereas serial entrepreneurs complete an entrepreneurial project before starting the next one (Rosa and Scott 1999; Wright et al. 1997). Although they are a frequent and important phenomenon in entrepreneurship and for the economy, we lack a systematic understanding of the advantages or disadvantages of multiple business ownership: "How do habitual entrepreneurs search for and identify new opportunities? What factors influence the decision to pursue such opportunities? Do entrepreneurs with business ownership experience perform better than those without such experience?" (Ucbasaran et al. 2006, p. 2). The study of habitual entrepreneurs thus offers an opportunity to explore the emergence and exploitation of opportunities (MacMillan 1986).

(c) 2016 The Author(s). Open Access This article is distributed under the terms of the Creative Commons Attribution 4.0 International License (http://creativecommons.org/licenses/by/4.0/), which permits unrestricted use, distribution, and reproduction in any medium provided you give appropriate credit to the original author(s) and the source, provide a link to the Creative Commons license, and indicate if changes were made. 
Research on habitual entrepreneurs has mainly focused on a human capital and an organizational perspective. The human capital perspective tries to answer important questions concerning how specific entrepreneurial experiences can give habitual entrepreneurs an advantage over novice entrepreneurs (Amaral et al. 2009; Ucbasaran et al. 2006). The organizational perspective tries to understand the mechanisms of the development of business groups and how business groups enable growth for habitual entrepreneurs (Iacobucci and Rosa 2005, 2010; Lechner and Leyronas 2009; Rosa and Scott 1999). We extend this approach by focusing on the social capital of habitual entrepreneurs and by distinguishing how social capital has different roles for serial and portfolio entrepreneurs in the case of opportunity emergence and exploitation.

There are two main streams for explaining opportunity emergence: discovery and construction. While we will not enter into the debate on whether they are substitutes or complements (see Suddaby et al. 2015), habitual entrepreneurs can be studied from both perspectives. On the one hand, it can be argued that the unique experience of habitual entrepreneurs allows them to see opportunities that cannot be seen by others through a form of imprinting (Mathias et al. 2015), but on the other hand, they are also more capable of acting upon their environment in order to construct opportunities (Alvarez et al. 2015). However, we do not know exactly why and how habitual entrepreneurs come to be convinced of the existence of new opportunities and how they exploit them.

Three important themes emerge when we extend the opportunity emergence question to habitual entrepreneurship: how did the opportunity originate (the question of opportunity origin), how was the team built (the question of team building), and how were the resources attracted (the question of resource attraction)?

A number of studies have contributed to understand the phenomenon of the habitual entrepreneur (Wiklund and Shepherd 2008). For the most part, these dealt with the differences between novice and habitual entrepreneurs (Hsu 2003, 2005; Iacobucci 2002; Westhead and Wright 1998, 1999; Westhead et al. 2003). However, despite the positive influences one would expect from having previously participated in entrepreneurial projects, empirical evidence of a positive correlation between habitual entrepreneurship and corporate success is rather inconclusive (Carter and Ram 2003; Schollhammer 1991). To be able to assess the influence of these groups on the success of ventures, another perspective is helpful. The focus shifts here from the comparison and examination of the similarities and differences between novice and habitual entrepreneurs to asking the question of why and how habitual entrepreneurs are different when acting upon emerging opportunities in terms of their social capital.

Moreover, research tends to view habitual entrepreneurs as a rather homogeneous group neglecting to account for differences in experience (e.g., the number of ventures created and their outcome) or entrepreneurial processes (Kirschenhofer and Lechner 2012). Therefore, the exploration of differences between serial and portfolio entrepreneurs based on their social capital appears a fruitful route of inquiry.

A critical assessment of the state of the field in entrepreneurship called for more qualitative research to generate new theory about opportunity emergence (Suddaby et al. 2015). Given the type of questions (how and why) and the novelty of these questions in research on habitual entrepreneurs, we opted for a case study methodology (Yin 2003). The case findings show that opportunities leading to new venturing emerge 
differently for portfolio and serial entrepreneurs. Portfolio entrepreneurs can rely on a wider weak tie network and new venturing is more based on continuous relationships and obligations while serial entrepreneurs can make more radical, riskier choices accepting the inherent uncertainty in the new venture.

\section{Review of the guiding literature}

\section{Opportunity emergence ${ }^{1}$ and social capital}

Entrepreneurship is about recognizing an opportunity and exploiting that opportunity (Shane and Venkataraman 2000). The ability to identify and select opportunities prior to their execution plays an important role and is an important characteristic of an entrepreneur (Vaghely and Julien 2010). The recognition of opportunities is related to alertness to opportunities and knowledge of markets and customers (Baron 2006). Habitual entrepreneurs seem thus be in an advantageous position to recognise opportunities. Indeed, habitual entrepreneurs identify more opportunities than novice entrepreneurs (Ucbasaran et al. 2003b). Due to their previous experience, they are potentially better able to assess opportunities and thus to differentiate between inferior and superior opportunities. However, opportunity emergence and exploitation is rarely the outcome of isolated processes within a company (Roininen and Ylinenpää 2010) but require the access and or acquisition of appropriate resources (McGrath and MacMillan 2000). The access to resources is possible because of the development of social networks (Aldrich and Zimmer 1986). Social networks are the potentially most valuable relationships that an entrepreneur or the entrepreneurial team holds: they help to identify business opportunities and attract human and financial resources but also to gain legitimacy (Lechner and Dowling 2003; Stam 2010).

The value of social networks can be summarized under the concept of social capital theory that is "used to describe the instrumental benefits of social relationships" (Aldrich and Martinez 2001, p.47). Social capital is defined as "resources embedded in a social structure which are or accessed and/or mobilized in purposive action" (Lin 1999, p.35). Social capital is created through investment in social relationships, leading to the creation of socially embedded resources that can be mobilized by individuals (Lin 1999). Social capital allows therefore to achieve objectives that were otherwise difficult to obtain based on the assumption that the social resources of entrepreneurs are more important than the possession of personal resources (Lin 1999).

In this sense, habitual entrepreneurs had the possibility through past entrepreneurial experience to develop social capital. It has been argued that network partners from previous projects play an important role for the identification and exploitation of new opportunities (Ucbasaran et al. 2003b). That means that social capital developed in previous ventures should positively influence opportunity emergence. Networks have an important function for entrepreneurs. They help to overcome disadvantages ensuing from "newness" and "size problems" (Hart et al. 1995; Lechner 2003; Stinchcombe 1965) by making resources available (Baum et al. 2000; Johannisson 1987; Wisnieski and Dowling 1997). The use of external resources can reduce the risk for the entrepreneur in the entrepreneurial project and increase the chances of success (Starr and MacMillan 1990). In this sense, networks can be both a means of discovering or constructing opportunities, as well as a way to see more or construct more (see, e.g., Alvarez et al. 2015). 
Granovetter $(1973,1974,1995)$ divides the relationships between the network players into weak and strong ties, according to their intensity. Within the strong tie framework, in-depth information and resources are exchanged (Brüderl and Preisendörfer 1998; Hoang and Antoncic 2003). Weaker ties frequently provide access to newer and more diverse information (De Koning and Muzyka 1996) and connect different groups in a sub-network (Granovetter 1973). The important aspect seems to be a balanced relationship between weak and strong ties (Krackhardt 1992) as even though strong ties guarantee faster access to important information and resources, weak ties prevent the network from becoming isolated from the outside world (Lechner et al. 2006). Diversified networks consist of bridging ties that connect an entrepreneur to different groups or communities (Granovetter 1973; McEvily and Zaheer 1999). Diversified networks can provide diversified resources (Burt 1992).

Research assumes that habitual entrepreneurs have developed superior social capital compared to novice entrepreneurs as they have already had the chance to build up these networks in previous projects for use in subsequent ventures (Lamont 1972; McGrath 1996; Starr and Bygrave 1991). This begins with the identification of new opportunities that are either brought to the attention of the habitual entrepreneur via the network or are further developed with the help of network partners (McGrath 1996; Ucbasaran et al. 2003b). In addition, the existing networks are beneficial to habitual entrepreneurs for the recruitment of suitable staff (Hsu 2004; Iacobucci and Rosa 2004) and for the financing of the new project with external capital (Hsu 2003; Scott and Rosa 1996; Westhead et al. 2003).

Network connections do not, however, always have a positive effect on the success of a project. Particularly in the case of previously successful entrepreneurs, strong ties can lead to the formation of "clubs" where the members have known each other for a long time and support each other time and time again, without adapting to changing environmental conditions (Starr and Bygrave 1991). This makes the identification of novel opportunities using network partners more difficult as these are often conveyed by weak ties (De Koning and Muzyka 1996; Harrison et al. 2001). Despite the existing research, it is not clear how habitual entrepreneurs actually use their social capital for identifying opportunities and whether opportunity emergence is different for serial and portfolio entrepreneurs.

\section{Execution of the opportunity and social capital}

Following the identification and positive assessment of an opportunity, it must be executed to move the entrepreneurial project from the planning to the implementation phase. It is the execution of this step that differentiates entrepreneurs from people who have never run a business (McMullen and Shepherd 2006). Habitual entrepreneurs go one step further; they execute more than one opportunity during their lifetime (Rosa and Scott 1999; Ucbasaran et al. 2006).

But which capabilities and resources can be transferred from one project to the other by habitual entrepreneurs? And which of them have a positive effect on the success of the new project? Timmons and Spinelli (2003) describe the entrepreneurial process as a balanced interaction between the opportunity, the team, and the resources. Experienced entrepreneurs in particular tend to cooperate more with larger teams to 
implement opportunities than novice entrepreneurs (McKelvie and Cedere 2001). By involving more team members, additional experience, knowledge, and know-how can be integrated into the project. Portfolio entrepreneurs in particular can overcome the limiting factor "time" by integrating additional partners (Iacobucci and Rosa 2004, 2010; Lechner and Leyronas 2009). Time is apparently critical for portfolio entrepreneurs in the process of implementing a new opportunity or new activities because, on average, they need longer to execute new activities than "serial" or "novice entrepreneurs" (Alsos and Kolvereid 1998). On the other hand, portfolio entrepreneurs can use resources from their current ventures for their new projects, especially support functions. This lowers costs and provides professional know-how for the project (Carter and Ram 2003). But the problem of time usually remains for the portfolio entrepreneurs because they are often still involved in the executive management of the current venture. Some of the portfolio entrepreneurs create business groups to overcome the organizational problems of managing more the one venture at the same time (Iacobucci and Rosa 2010; Lechner and Leyronas 2009).

According to the resources-based view, entrepreneurial opportunities exist because potential players in a market have access to different resources and have different ideas about the value and the transformation of these resources into new products and services (Shane and Venkataraman 2000). Access to different resources and ideas is largely a function of social capital. Entrepreneurs who are able to gain access to more resources are more successful than others (McKelvie and Cedere 2001). Habitual entrepreneurs do have better access to resources (Westhead et al. 2004). They can use their social that they built up during their previous entrepreneurial projects, human resources, other assets, and, if a previous project was successful, they bring in financial resources (Carter and Ram 2003). But the question of how and under which circumstances habitual entrepreneurs use these resources has not yet been answered nor whether serial and portfolio entrepreneurs differ in regards of social capital.

In essence, it is not clear what role social capital plays for opportunity emergence and exploitation of serial and portfolio entrepreneurs.

\section{Case studies description of habitual entrepreneurs Entrepreneur A-portfolio entrepreneur}

Entrepreneur A joined his family's media company in the late 1980s. In 1996, he became the managing director. To this day, the company's core business is the publication of newspapers. However, entrepreneur A diversified the activities by founding companies responsible for the expansion and reorganization of the core business and other activities, such as investments and hobbies. Altogether, he was involved in the founding of eight entrepreneurial firms $\left(\mathrm{P}_{\mathrm{A} 2}\right.$ to $\left.\mathrm{P}_{\mathrm{A} 9}\right)$. In 2003, the publishing house had a turnover of 85 million $€$, employed 550 full-time and approx. 5000 part-time workers, who were mainly involved in distribution.

In 1993, entrepreneur A set up a marketing firm within the publishing house for the development, printing, and distribution of advertising material in his region $\left(\mathrm{P}_{\mathrm{A} 1}\right.$ is entrepreneur A's first project). Some years later, he set up a 60/40 venture with a newspaper company in a neighboring region to increase the potential number of households reached by the marketing company. In 2002, the group then took over a regional post 
provider $\left(\mathrm{P}_{\mathrm{A} 3}\right)$. In addition to this, the company holds minority shares in a television station as well as two radio stations and supports a number of social organizations. In 1999, entrepreneur A reorganized the ownership structures of the publishing house. An additional company was set up, not for "entrepreneurial activities," but more to work around legal- and tax-related problems. The third area where entrepreneur A is entrepreneurially active can be described as "other activities, investments and hobbies outside of the family firm." In 1998, he set up a leasing company for machines and cars with a long-time friend and experts from the motor car industry $\left(\mathrm{P}_{\mathrm{A} 5}\right)$.

Entrepreneur A set up a further company in the film industry $\left(\mathrm{P}_{\mathrm{A} 6}\right)$. The company was set up in the USA with a partner who had experience in the branch and mainly produced crime and action films. Following the fusion with a competitor, the annual turnover of the company was approx. 28 million USD. At this point in time, the owners had set their sights on a successful stock market launch. Following the turbulences in the financial market in 2001, the company was plagued by financial problems and had to file for bankruptcy. This was the only project that entrepreneur A was involved in that failed and had to be written off completely. Entrepreneur A was though still active in two other fields. One of the projects invested in real estate within the region and rented out, among other things, office and storage space to the leasing company $\left(\mathrm{P}_{\mathrm{A} 5}\right)$ and the publishing house. Entrepreneur A's most recent project involves alternative energy $\left(\mathrm{P}_{\mathrm{A} 8}\right)$. These investments are also carried out with a partner with the necessary market expertise.

Entrepreneur A invests in different companies in different branches. His personal principles are very important to him here. His investing in a new product is dependent on a great number of criteria. A very important criterion is having a partner with market knowledge and experience in the branch who is willing to act as managing director of the new company. The partner normally has holdings in the firm, but entrepreneur A usually holds the majority.

When asked why he has invested in different fields, after brief consideration, entrepreneur A replied, "I have four children and each of them should have the opportunity to work in our family firm in an area that interests them."

\section{Entrepreneur B-the serial entrepreneur}

Entrepreneur $B$ has set up four businesses in the last 36 years. The first business was in the building industry $\left(\mathrm{P}_{\mathrm{B} 1}\right.$ [for the first project by entrepreneur $\left.\left.\mathrm{B}\right]\right)$, the second one was in the furniture industry $\left(\mathrm{P}_{\mathrm{B} 2}\right)$, and the current one is in the travel industry $\left(\mathrm{P}_{\mathrm{B} 3}\right)$. In addition, entrepreneur $\mathrm{B}$ was involved in the setting up of a marketing firm that is still in existence $\left(\mathrm{P}_{\mathrm{B} 4}\right)$ and which developed out of $\mathrm{P}_{\mathrm{B} 3}$.

In 1969, entrepreneur B set up a business for renovating concrete components on buildings and tunnels. In return for his willingness to try out a new chemical, the supplier paid the bill for a year. The rest of the finances were covered by a bank loan and personal loans from two friends. During the boom period, the company virtually held the monopoly in this niche market in the large cities of West Germany and employed more than 60 people. During the late 1970s and the early 1980s of the last century, the market changed as a result of the shift from public sector customers to private customers with poor payment practices, and a sink in 
the average quantity of orders. These changes in the market conditions led to a higher bureaucratic burden and a decrease in entrepreneur B's satisfaction. He sold the business in 1984.

Following the sale of $\left(\mathrm{P}_{\mathrm{B} 1}\right)$, entrepreneur $\mathrm{B}$ visited a furniture congress in Milan with a partner and then spontaneously set up a business to import Italian designer leather furniture $\left(\mathrm{P}_{\mathrm{B} 2}\right)$. He invested the complete sales proceeds from $\left(\mathrm{P}_{\mathrm{B} 1}\right)$ as equity. The furniture was supplied by an Italian producer network and sold by entrepreneur B in three shops in different large German cities. The business should have been declared bankrupt, but entrepreneur B opted to fulfill all of his obligations to customers, employees, and shop owners. Legal disputes with the Italian suppliers were not successful on account of bankruptcies and diverse restructurings and new start-ups among the Italian firms. Entrepreneur B lost his entire fortune and was almost penniless in 1987. He himself views this basically negative experience as an enriching experience which, in turn, had a positive influence on the start up project that followed. In future, he will, for example, no longer make himself dependent on external business partners but will connect them to new projects by creating win-win situations.

While visiting New Zealand, entrepreneur B and two additional people developed the idea of customized trips to New Zealand. The two partners from New Zealand set up firms in New Zealand and Australia, while entrepreneur B and a partner set up a business in Germany to canvass for customers. At this point in time, none of the four partners had any experience in the travel branch. In 2004, the firm had a turnover of 15 million Euro and operated at a profit. At the beginning of 2005, the firm employed 32 people. In the same year, a further six jobs were created and more office space was rented and developed.

In 1998, a marketing firm $\left(\mathrm{P}_{\mathrm{B} 4}\right)$ was set up as a $100 \%$ subsidiary of $\left(\mathrm{P}_{\mathrm{B} 3}\right)$. This firm was not set up to access new areas of business or additional growth for the business or parent company, but to outsource some marketing activities to profit from certain market conditions, such as discounts from publishers for agencies. Entrepreneur B's motivation is the desire for independence. In his own words, money is important for implementing business projects and making growth possible. Personal wealth though is not that important to him and not a motivation behind his entrepreneurial activities.

\section{Entrepreneur C-portfolio entrepreneur}

Entrepreneur C founded his first company in 1990 in the food sector as a solo entrepreneur. The project did not take off and he sold the company to a local investor without recovering his initial investment. In 1995, he started another company in the food sector in southwest France with his wife and brother-in-law. The company was the result of their previous unsuccessful venture and they joined forces. It had sales of about $\$ 200,000$ in its first year and reached breakeven in its second year of existence. Over a 10-year period, entrepreneur $\mathrm{C}$, as the main driver of activities, added three new ventures in the food business and reached a sales level of \$ 130 million. In 2010, the entrepreneurs ventured into the hospitality service industry by creating their first hotel, followed by a second in 2012. Finally, he created a new venture for complementary services for hotels. 


\section{Entrepreneur D-serial entrepreneur}

Entrepreneur D created his first venture with a friend in 2003; given his personal interest in China, the company was dedicated to importing activities from there. In 2005, he joined a Master's program in entrepreneurship in France. The same year, he ceded his participation to his former partner and left the business. He met an engineer in the Master's program who was interested in doing business in China and in 2006, together with a Chinese partner, they started a consulting company for French companies looking for engineering solutions in China. Due to unresolved conflicts with his partner about the strategic direction of the firm, he left the company in 2008. He then created a firm with three former classmates that had started an import business from China. The company specialized in services and products for university ceremonies. It targeted the French market and reached 2 million $€$ in sales within 3 years. In 2011, he and another partner left the firm to dedicate themselves to other activities. The other partner took over his family business while entrepreneur D became interested in reasonable, alternative, and sustainable food production. He explored the idea for about a year and started the new venture in 2012, adding a partner with technical competences in the same year.

\section{Social capital and the emergence of new opportunities by habitual entrepreneurs}

In the following, we will use entrepreneurs $A$ and $B$ as the main cases and entrepreneurs $\mathrm{C}$ and $\mathrm{D}$ as complementing, control cases.

\section{Entrepreneur A's network}

Entrepreneur A had developed strong social capital that has led to a wide and diverse network. He enjoys a high social standing as the publisher of the newspaper with the highest circulation in a medium-sized city. He is active in diverse social organizations and is involved in volunteer work within and outside the region, leading to an increasing network of strong and weak ties. In his hometown, he does at times feel the "envy" of those around him, which makes him very careful when choosing business partners and limits the number of potential partners. He also avoids doing business with close friends as he does not want business problems to weigh on the friendship.

Entrepreneur A divides business partners into "real business partners," who bring in project-specific knowledge, and "supporting partners." "Real business partners" are those ties that leverage-specific resources and competences without which a project could not be carried out. The "supporting partners," such as lawyers, and consultants, who mainly provide supporting and rather business-general services, are, in the entrepreneur's perception, relatively easy to replace. Many of these "supporting tasks," being also considered generic enough, are taken on by internal departments within the publishing house.

The number of potential business partners identified by entrepreneur $\mathrm{A}$ is limited due to the narrow regional focus and the concentration on certain areas of business. Thus, for the joint venture involving the distribution of advertising material in the 
neighboring region, there was only one potential partner who could provide $100 \%$ access to the households in the region.

Generally, the number of potential business partners per project is very limited. A further reason for the low number of potential business partners (except in the case of $\mathrm{P}_{\mathrm{A} 6}$ ) is the fact that entrepreneur A mostly develops his business ideas with partners from his existing networks. All companies are based on a relationship of trust between entrepreneur A and his partners. A high number of weak ties make it possible for him to search the market for business concepts. Before he invests money though, he transforms these weak ties into strong ones. To do this, entrepreneur A invests time in building up trust in potential partners. Even before the implementation of the actual "entrepreneurial" projects, he carries our small business transactions with his future partners to check their professional qualifications. If the potential partner is not prepared to invest time in cementing the ties, then entrepreneur A will abort the project if need be. Using this approach, entrepreneur A develops such strong partnerships that the reputation of the branch and business partner becomes less important for him. It appears that the existence of a business group as a form of portfolio entrepreneurship influences the choice of relational properties when carrying out new ventures. The relational properties in this sense are the predominance of strong ties in the business partner network. Developing strong ties requires interaction over time. Thus, the time leading up to the entrepreneurial event is lengthened (Table 1).

During the eight projects, the active network of business partners was not very stable (see Table 1). With the exception of the activities within the publishing house, investments were in non-related business fields. As entrepreneur A does not have any special knowledge of these markets, he seeks business partners who have knowledge of and experience in this field to gain a competitive advantage. The supporting network is however relatively stable. Nevertheless, entrepreneur A does not want to be completely dependent on these partners. They are categorically replaceable.

Entrepreneur A's motivation is not purely of a monetary nature. He does, of course, expect good returns and sets high expectations for each project, which have to be absolutely satisfied. At the same time though, family and social awareness also play an important role. For entrepreneur A, the social network is the most important factor for finding business ideas. A great number of weak ties lead to a high flow of information. His networks provide contact to a vast number of potential entrepreneurs in different branches. The identification, selection, and development of new opportunities is guided by his knowledge and experience in the core business, his instinct for opportunities, his beliefs and hobbies, and his entrepreneurial mindset. He is

Table 1 Entrepreneur A's network

\begin{tabular}{|c|c|c|c|c|c|c|c|c|c|}
\hline & & \multicolumn{8}{|c|}{ Project } \\
\hline & & $P_{\mathrm{A} 1}$ & $P_{A 2}$ & $P_{A 3}$ & $\mathrm{P}_{\mathrm{A} 4}$ & $P_{\mathrm{A} 5}$ & $P_{A 6}$ & $P_{A 7}$ & $P_{A 8}$ \\
\hline \multirow{4}{*}{$\begin{array}{l}\text { Business partners and "supporting" partners } \\
\text { according to importance }\end{array}$} & $1 \mathrm{st}$ & $A_{A}$ & $A_{A}$ & $A_{A}$ & $A_{A}$ & $F_{A}$ & $\mathrm{H}_{\mathrm{A}}$ & $\mathrm{F}_{\mathrm{A}}$ & $G_{A}$ \\
\hline & 2nd & & $\mathrm{B}_{\mathrm{A}}$ & $C_{A}$ & $D_{A}$ & $\mathrm{G}_{\mathrm{A}}$ & $I_{A}$ & $\mathrm{G}_{\mathrm{A}}$ & \\
\hline & $3 r d$ & & & & $E_{A}$ & $\mathrm{~K}_{\mathrm{A}}$ & $\mathrm{G}_{\mathrm{A}}$ & $\mathrm{K}_{\mathrm{A}}$ & \\
\hline & 4th & & & & & & $J_{A}$ & & \\
\hline
\end{tabular}

Partner $A_{A}$ brother of entrepreneur $A$, Partner $B_{A}$ newspaper from a bordering region, Partner $C_{A}$ previous owner of the company, Partner $D_{A}$ tax consultant 1 , Partner $E_{A}$ members of the family, Partner $F_{A}$ friend, specialist in the automotive industry, Partner $G_{A}$ three banks, Partner $H_{A}$ friend, Partner $I_{A}$ investment funds, Partner $J_{A}$ lawyers, Partner $K_{A}$ tax consultant 2 
able to bring his knowledge, experience, or, at the very least, his interests into every project.

The team concept is important within the implementation framework. At the start of every project, entrepreneur A looks for a partner with market knowledge, experience, and, if possible, technical know-how. As a result of most of the investments being of a local or at least regional character, he is better able to assess his partner. The only investment that did not take place in southern Germany was not successful.

Entrepreneur A allows for enough time to establish strong ties with business partners. This helps him to assess the character, knowledge, and market experience of the partner, and also to understand the branch itself. He invests equally in both the business idea and the business partner. This trust building process can take months, or even years. Alongside his network, entrepreneur A contributes a wealth of material and nonmaterial resources to the project. In addition to financial resources, he also provides support from the specialist departments in the publishing house.

In this case study, the stability of different networks varied. Two types of relationship were particularly steady. One was the close family relationship, the other the steady financial network. In $50 \%$ of his projects, he worked with these partners. All of the large German banks and additional regional banks can be found in his hometown. Nevertheless, he mainly works with three banks and combines their loans in a project. The financial network appears to be relatively steady. It is comprised though of several partners to avoid being dependent on one partner alone. It was the network of partners with experience in the branch that proved to be less stable. In the case of entrepreneur A, this is due to the high degree of diversification in the projects.

\section{Entrepreneur B's network}

The activated network partners of entrepreneur $B$ were absolutely independent of each other (except in $\mathrm{P}_{\mathrm{B} 4}$ ) in each individual business start-up. With the start up of $\mathrm{P}_{\mathrm{B} 1}$ and $\mathrm{P}_{\mathrm{B} 2}$, the great distance in time (15 years) between the ventures is sure to have played an important role for the changes within the networks. However, the complete network of activated partners also changed between $\mathrm{P}_{\mathrm{B} 2}$ and $\mathrm{P}_{\mathrm{B} 3}$. These changes can be traced back to the completely different business areas and the failure of $\mathrm{P}_{\mathrm{B} 2}$ (Table 2).

Table 2 Entrepreneur B's network explanation of terms

\begin{tabular}{lllllll}
\hline & & & & & \\
\cline { 4 - 7 } & & $P_{B 1}$ & $P_{B 2}$ & $P_{B 3}$ & $P_{B 4}$ \\
\hline Business partners and "supporting" partners & $1 s t$ & $A_{B}$ & $F_{B}$ & $H_{B}$ & $I_{B}$ \\
according to importance & 2nd & $B_{B}$ & $G_{B}$ & $I_{B}$ & \\
& 3 rd & $C_{B}$ & & & \\
& 4 th & $D_{B}$ & & & \\
& 5 th & $E_{B}$ & & & \\
& 6 th & & & & & \\
\hline
\end{tabular}

Partner $A_{B}$ German chemical company, Partner $B_{B}$ public client, Partner $C_{B}$ bank, Partner $D_{B}$ two friends (creditors), Partner $E_{B}$ US chemical company, Partner $F_{B}$ co-founder of company $P_{B 2}$, Partner $G_{B}$ Italian partner, Partner $H_{B}$ two partners in New Zealand and Australia, Partner $I_{B}$ co-founder 
For $\mathrm{P}_{\mathrm{B} 1}$, entrepreneur B's networks played an important role in the identification of opportunities and the financing. When setting up firm $\mathrm{P}_{\mathrm{B} 2}$, entrepreneur B's private network was the driving force in identifying the opportunity. Without his partner (referred to in the table representing entrepreneur B's networks as $F_{B}$ ), this opportunity would never have caught his attention. At the same time, the network was the critical weakness and caused the failure of the business model. The network was too small at the critical point, and this led to a dependence on a few partners in the area of production. The network also played an important role during the setting up of the third firm $\mathrm{P}_{\mathrm{B} 3}$. Together with partners from the existing network, to whom there were strong ties, the opportunity was identified and implemented. $\mathrm{P}_{\mathrm{B} 4}$ was set up solely for a costefficient handling of existing processes. It should be noted that the members of the founding team of $\mathrm{P}_{\mathrm{B} 2}$ and $\mathrm{P}_{\mathrm{B} 3}$ had no experience in the specific industries. Their existing networks were also not able to contribute this experience.

What is striking is the ability of entrepreneur B to identify market niches in different business fields. His strong entrepreneurial mindset allows him to analyze his idea very quickly and develop opportunities. He then reacts very quickly to the situation and finds suitable partners within a short space of time, motivates them, and gets them involved. Entrepreneur B's personal network was the decisive element for the identification of opportunities in all start-ups (except $\mathrm{P}_{\mathrm{B} 4}$ ).

The creation of the start-up team was less systematic and not necessarily based on complementarity of competences. In two of the three start-ups, $\left(\mathrm{P}_{\mathrm{B} 2}\right.$ and $\left.\mathrm{P}_{\mathrm{B} 3}\right)$, friends were involved in the project as co-founders (the firm $\mathrm{P}_{\mathrm{B} 4}$ is not treated as an independent venture here). However, he is able to build up effective support networks at very short notice. Entrepreneur B's networks proved to be very unstable during the start-ups $\mathrm{P}_{\mathrm{B} 1}, \mathrm{P}_{\mathrm{B} 2}$, and $\mathrm{P}_{\mathrm{B} 3}$. This could be due to the long period of time between the projects $\mathrm{P}_{\mathrm{B} 1}$ and $\mathrm{P}_{\mathrm{B} 2}$. It could also be the result of the failure of $\mathrm{P}_{\mathrm{B} 2}$ as well as the very different branches in $\mathrm{P}_{\mathrm{B} 2}$ and $\mathrm{P}_{\mathrm{B} 3}$. Entrepreneur $\mathrm{B}$ hardly ever transfers resources from one project to another.

\section{Entrepreneur C's network}

Similar to entrepreneur A, the partner network of entrepreneur $\mathrm{C}$ is relatively small across the ventures. After a first attempt as a solo entrepreneur, $\mathrm{C}$ joined forces with his wife and brother in law in the food distribution business $\left(\mathrm{P}_{\mathrm{C} 1}\right)$, relying mainly on suppliers for production and concentrating on marketing and distribution. $\mathrm{P}_{\mathrm{C} 2}$ was an extension of $\mathrm{P}_{\mathrm{C} 1}$ since it consisted in setting up a production company. For this venture, the initial team remained the same but a new partner competent in production was added. Financing was secured by a new bank. The search of the new partner took about 18 months since entrepreneur $\mathrm{C}$ wanted to be sure to find a trustful partner. $\mathrm{P}_{\mathrm{C} 2}$ allowed the firm to penetrate better the food market, differentiate from the competition and let to substantial growth. Being the CEO of these companies allowed $\mathrm{C}$ to get more and more involved in the local business ecosystem participating in various support activities for young entrepreneurs, an entrepreneurs business club, and other associations that were functional for the existing businesses but also for the emergence of new opportunities. Thus, $\mathrm{C}$ was able to develop a large weak tie network. $\mathrm{P}_{\mathrm{C} 3}$ was again in the food business. The business idea was brought to $\mathrm{C}$ by a former supplier and competitor 
with whom he created the company. $\mathrm{P}_{\mathrm{C} 4}$ was in the education business, an idea brought to $\mathrm{C}$ by a long-standing business contact. Even if this business was in a new domain, the same bank continued to finance the venture as a demonstration of the strong relationship develop between $\mathrm{C}$ and the bank. This was even more true for $\mathrm{P}_{\mathrm{C} 5}$ and $\mathrm{P}_{\mathrm{C} 6}$ after $\mathrm{P}_{\mathrm{C} 4}$ had failed. These last two ventures were started by $\mathrm{C}$ with his wife and their daughters in the hotel and hotel service business.

C's partner network is characterized by a high stability involving usually family members. $\mathrm{C}$ tends to complement the team with partners that bring missing competences to the new venture. Generally, these partners have been known for a long time. The initial success of $\mathrm{C}$ in the food business has led to stable financing relationships. $\mathrm{C}$ relied for five ventures on the same financing partner.

\section{Entrepreneur D's network}

Entrepreneur D's new ventures were literally new ventures. Co-founders and financing partners of this serial entrepreneur changed from venture to venture. $\mathrm{P}_{\mathrm{D} 1}$ involved a close friend and his father for financing. $\mathrm{P}_{\mathrm{D} 2}$ was linked to a change in his life when he went back to higher education where he met partners for the next venture. From $\mathrm{P}_{\mathrm{D} 2}$, he carried over a founding partner and teamed up with another former classmate to launch $\mathrm{P}_{\mathrm{D} 3}$. When in entrepreneur D's view, this business became too routinized, he existed $\mathrm{P}_{\mathrm{D} 3}$ and launched $\mathrm{P}_{\mathrm{D} 4}$. For this innovative food business, he teamed up with a $\mathrm{PhD}$ in nutrition.

Generally, D's different ventures relied on different partner networks. New venturing is characterized by strong discontinuities that are partly due to changes in lifestyle but also D's general attitude to seek out for new challenges. When creating a new venture, $\mathrm{D}$ is willing to accept that he enters again in heaving learning situation that he needs to develop a business from scratch without relying on past relationships or achievements (Tables 3 and 4).

\section{Results and discussion}

\section{Case conclusions: social capital and the emergence of opportunities}

The portfolio entrepreneurs are frequently confronted with ideas about new opportunities emerging from their weak tie networks. Together with the future partners, they develop opportunities from ideas and are very conscious of their role and the role of their partners (compare, e.g., Ardichvili et al. 2003; Baron 2006). They only participate

Table 3 Entrepreneur C's network

\begin{tabular}{llllllllll}
\hline & \multicolumn{1}{c}{ Project } & & & \\
\cline { 3 - 9 } & & $P_{C 1}$ & $P_{C 2}$ & $P_{C 3}$ & $P_{C 4}$ & $P_{C 5}$ & $P_{C 6}$ \\
\hline Business partners and "supporting" partners according & 1 st & $A_{C}$ & $A_{C}$ & $B_{C}$ & $A_{C}$ & $A_{C}$ & $A_{C}$ \\
to importance & 2nd & $B_{C}$ & $B_{C}$ & $F_{C}$ & $I_{C}$ & $I_{C}$ & $L_{C}$ \\
& 3 rd & $C_{C}$ & $D_{C}$ & $G_{C}$ & $D_{C}$ & $K_{C}$ & $I_{C}$ \\
& 4 th & & $E_{C}$ & $D_{C}$ & & & $D_{C}$ & $K_{C}$ \\
& 5 th & & & & & & & & $D_{C}$ \\
\hline
\end{tabular}

Partner $A_{C}$ wife of entrepreneur $C$, Partner $B_{C}$ brother-in-law, Partner $C_{C}$ bank 1, Partner $D_{C}$ bank 2, Partner $E_{C}$ co-founder 1 , Partner $F_{C}$ co-founder 2, Partner $G_{C}$ ex-competitor, co-founder 3, Partner $H_{C}$ friend, co-founder 4, Partner $I_{C}$ co-founder 5 , Partner $J_{C}$ daughter 1 , Partner $K_{C}$ daughter 2, Partner $L_{C}$ co-founder 5 
Table 4 Entrepreneur D's network

\begin{tabular}{|c|c|c|c|c|c|}
\hline & & \multicolumn{4}{|c|}{ Projects } \\
\hline & & $P_{C 1}$ & $P_{C 2}$ & $P_{C 3}$ & $P_{C 4}$ \\
\hline \multirow{3}{*}{$\begin{array}{l}\text { Business partners and "supporting" partners } \\
\text { according to importance }\end{array}$} & $1 \mathrm{st}$ & $A_{D}$ & $C_{D}$ & $D_{D}$ & $\overline{H_{D}}$ \\
\hline & 2nd & $B_{D}$ & $D_{D}$ & $F_{D}$ & $I_{D}$ \\
\hline & $3 r d$ & & $E_{D}$ & $G_{D}$ & $J_{D}$ \\
\hline
\end{tabular}

Partner $A_{D}$ friend, co-founder 1, Partner $B_{D}$ father (financer), Partner $C_{D}$ study colleague, co-founder 2, Partner $D_{D}$ study colleague, co-founder 3, Partner $E_{D}$ bank 1, Partner $F_{D}$ study colleague, co-founder 4, Partner $G_{D}$ bank 2 , Partner $H_{D}$ researcher, co-founder 5 , Partner $I_{D}$ business angel, investor, Partner $J_{D}$ venture capitalist, investor

in projects of which they have a basic understanding. Some of the opportunities, in the case of entrepreneur A, such as the establishment of delivery services for advertising material, could possibly have been implemented within the existing firm. The same reasoning applies also for the first three and last three ventures of entrepreneur $\mathrm{C}$ (food industry, hospitality services). As has been found in research on business groups (Lechner and Leyronas 2009), risk diversification and resource attraction are explaining factors. Several small units reduce the risk for the entire business structure (Sarasvathy and Menon 2004; Westhead and Wright 1999). In addition, taxand family-related issues also play an important role for entrepreneur A (Birley and Westhead 1993; Donckels et al. 1987; Westhead and Wright 1998).

Entrepreneur B, on the other hand, comes across ideas almost by chance. He can familiarize himself quickly with the subject and develop the idea into an opportunity without any great assistance. He is very enthusiastic and relies largely on intuition for identifying opportunities. He does not analyze the opportunities to death (McGrath and MacMillan 2000, p. 3). He implements opportunities that interest him with the resources at hand or opportunities that have originated through a series of coincidences (Baker and Nelson 2005; Lechner and Kirschenhofer 2004). Entrepreneur D moves along changing lines of interest, accepting of being in a substantial learning situation in a new venture and adapting relatively fast to new contexts.

Opportunities are presented to both portfolio entrepreneurs several times a year by their networks. The network also plays an important role in the search for opportunities for the serial entrepreneurs. However, the opportunities are not specifically presented by their network of weak ties. Rather, they develop them, whether by choice or coincidence, with partners from their networks who are connected to them by weak or strong ties. In contrast to the portfolio entrepreneurs, the serial entrepreneurs do not make use of tried and trusted routines to identify and test opportunities. The lack of pre-existing structure (such as a business group) allows for more deliberate and spontaneous choices for serial entrepreneurs. The cases also suggest that serial entrepreneurs are resigned to entering a new venture in a substantial learning situation (Gibb and Ritchie 1982).

In contrast, the portfolio entrepreneurs could use their reputation as a permanent entrepreneur to encourage potential entrepreneurs to present them with new opportunities. The serial entrepreneurs, on the other hand, participating in only one project at a time and, in the case of A, with relatively long periods of time between projects, do not have the reputation of being open to new projects at all times. To some extent, portfolio entrepreneurs are identified in a theoretical habitual entrepreneurs populations as active while the serial entrepreneurs are only latent in the intervals between 
ventures. The fact that the serial entrepreneurs are presented with fewer opportunities compared to the portfolio entrepreneurs could be the result of the lower number of weak ties. Entrepreneur A has a very extensive network of weak ties as a result of his reputation throughout the region, his volunteer work, and his interregional activities. It is similar with entrepreneur $\mathrm{C}$, who is involved regularly in coaching projects for young entrepreneurs.

In terms of the individual projects, the networks of the entrepreneurs can be divided into three groups: (1) the direct project network, (2) the network of weak ties that is involved in the project, and (3) the rest of the social network. The question, though, is what role do these individual networks play in future projects? According to the literature, habitual entrepreneurs use the direct project network to discover and implement new opportunities (Ucbasaran et al. 2003b). The case studies could not confirm this assumption. In the case of the portfolio entrepreneurs, opportunities were mostly presented by their weak ties. While the serial entrepreneur B did develop them with network partners, except in the case of firm $\mathrm{P}_{\mathrm{B} 4}$, which was developed to support firm $\mathrm{P}_{\mathrm{B} 3}$, it was not with partners from the direct partner networks of previous projects. Serial entrepreneur D was also developing new teams for each venture. In this sense, portfolio entrepreneurship increases the in-degree of ties (i.e., networking occurs, information flows from the outside in), while serial entrepreneurs need to constantly increase the outdegree of ties in order to have sufficiently rich networks. This finding adds an explanation to other research that found that portfolio entrepreneurship facilitates the attraction of resources (Lechner and Leyronas 2009).

The business network of an entrepreneur starts with his personal network. During his entrepreneurial activity, he expands this, and the business network increases in importance (Baum et al. 2000; Lipparini and Sobrero 1997). The growth of the network leads to an increase in the number of weak ties (Lechner and Dowling 2003; Witt 2004). Strong ties provide in-depth information and resources (Brüderl and Preisendörfer 1998; Hoang and Antoncic; 2003); weak ties, on the other hand, provide new information (De Koning and Muzyka 1996). However, bridging ties lead to new information for new opportunities. For portfolio entrepreneurs, the cases clearly suggest that an extensive network of weak ties has a positive effect on the number of opportunities. Over the course of many years, both portfolio entrepreneurs built up their networks through professional activities and volunteer work. New opportunities are presented to the portfolio entrepreneurs by their network of weak ties several times a year.

Alongside the question of the influence of the direct project network from previous projects on the identification of opportunities is the issue of what effect these contacts have on the success of the implementation. In principle, portfolio entrepreneurs in particular, as a result of their activities, have the opportunity to build up an extensive network of strong ties and to transfer these ties from one project to the next (Alsos and Carter 2003). Entrepreneur A makes use of this in two ways. First of all, he always offers his brother the chance to participate in the implementation of opportunities. $\mathrm{He}$ frequently takes supporting partners from one project into another, e.g., the three banks that have been financial backers of $50 \%$ of his projects. Entrepreneur $\mathrm{C}$ has a similar pattern with an increasingly stable financing network and involving family members in project. Both serial entrepreneurs, on the other hand, did not re-involve any important partners in the implementation of their serial projects. 
The stability of the core businesses of the portfolio entrepreneur with a changing periphery of businesses influences the startup of firms and the choice of the partners. It requires more stable foundations (strong ties) and less radical changes compared to the new ventures of a serial entrepreneur, where every new venture is potentially isolated without any necessary relations to the previous ones. Therefore portfolio entrepreneurs have access to more and more diverse resources since their ongoing ventures allowed them to build stronger social capital; serial entrepreneurs need to develop more actively social capital after having shown interest in new opportunities. Put in other words: Portfolio entrepreneurs can already mobilize resources from relationships while serial entrepreneurs need to invest more in relationships. However, the existing stock of social capital of the portfolio entrepreneurs and the need to continue investing in and maintaining existing relationships reduce their action autonomy. Serial entrepreneurs need to also have greater freedom to develop new social capital. Portfolio entrepreneurs remain somehow indebted to the existing social capital. The existing social capital creates also the reputation of portfolio entrepreneurs making them generally more risk-averse than serial entrepreneurs.

Proposition 1 Portfolio entrepreneurs are presented with opportunities by their networks more frequently than serial entrepreneurs, i.e., the in-degree of network relationships is higher for portfolio entrepreneurs compared to serial entrepreneurs. Potentially, portfolio entrepreneurs have larger weak tie networks than serial entrepreneurs.

Proposition 2 Past project partners have a lower probability to be involved in the identification and exploitation of new opportunities for serial than for portfolio entrepreneurs.

Proposition 3a Choices in setting up new ventures are more moderate and continuous for portfolio entrepreneurs compared to the possibility of serial entrepreneurs who have more autonomy to break with the past.

Proposition 3b Choices in setting up new ventures are more moderate and continuous for portfolio entrepreneurs: Generally, portfolio entrepreneurs will be less risk-friendly than serial entrepreneurs.

\section{Cross-case conclusions: how habitual entrepreneurs implement opportunities}

Successful habitual entrepreneurs mostly implement the opportunities together with partners (Donckels et al. 1987). In all four case studies, the direct project network was relatively small for serial and portfolio entrepreneurs. Teams play very different roles in the implementation of opportunities for the two types of habitual entrepreneurs. The portfolio entrepreneurs are dependent on the building of teams as they mostly do not have the necessary market knowledge or the time for implementation. Thus, the partners are more strongly involved in the operative management of the company. The portfolio entrepreneurs are dependent on competent partners who can be trusted as they are unable to involve themselves completely (Iacobucci and Rosa 2004, 2010). If portfolio entrepreneurs are unable to find suitable partners, they delay the implementation (Alsos and Kolvereid 1998). 
They take time to transform their weak ties into strong ones and thus build trust so that they can avoid risk (Aldrich and Zimmer 1986; Larson 1991). This course of action could be observed in both portfolio entrepreneurs. If entrepreneur A is interested in an opportunity that a weak tie has presented to him, he will generally discuss it with close friends and uses his existing network to implement it. He implements this by transforming the weak ties with the people who presented him with the opportunity into strong ties. It is with these partners that he implements the projects. The results of the case study confirm previous assumptions that it is more likely that weak ties give access to new information (De Koning and Muzyka 1996) and that strong ties supply more in-depth information and other resources (Brüderl and Preisendörfer 1998; Hoang and Antoncic 2003).

For the serial entrepreneurs, the existing team plays a more marginal role in the implementation of opportunities. Both familiarize themselves so deeply with the opportunity in order to develop the necessary expertise and complement it with partners. Being a serial entrepreneur means to work on one project at a time; they are not subject to time constraints comparable to those of a portfolio entrepreneurs. For example, in the project $\mathrm{P}_{\mathrm{B} 3}$, the partner and co-founder in the team was a friend. This had more to do with his friend's circumstances and the desire to have a partner than it being out of necessity. For new start-ups, entrepreneur B turns to the old direct project network if it is a similar project. If the new product has no connection to a previous firm, he will work with new partners. Serial entrepreneur $C$ chose partners for two subsequent ventures from his Master's class, but for his last project, he complemented his market expertise with the technical expertise that he did or could not acquire completely. Still, the main competences are held or acquired by the lead serial entrepreneur.

Entrepreneurs who have access to a high number of resources are more successful than others (McKelvie and Cedere 2001). Habitual entrepreneurs have better access to resources and can transfer these to the next project (Westhead et al. 2004). In the two cases of portfolio entrepreneurs, material and immaterial resources were regularly transferred from one firm to the next. These are, above all, financial resources, such as services carried out by departments in the original firm for the project. The serial entrepreneurs, on the other hand, hardly ever transfer resources from one project to the next.

Particularly strong ties within a network facilitate access to resources (Brüderl and Preisendörfer 1998; Hoang and Antoncic 2003). Portfolio entrepreneurs have the opportunity to transfer their networks directly from one firm to another (Alsos and Kaikkonen 2004). In the case study, we found that the reputational effect of the portfolio entrepreneur led to a high indegree of weak ties. The very large weak tie network is a resource option on its own. The resources mobilized, however, are strong ties rather than weak ties (Brüderl and Preisendörfer 1998; Hoang and Antoncic; 2003). By intensifying the relationships, entrepreneur A is able to transform weak ties into strong ones. Thus, he is able to gain access to the necessary resources. Entrepreneur $\mathrm{C}$ relies on trusted ties (interpersonal) who need to find partners with the necessary competences. In contrast, the serial entrepreneurs in the cases established a new network for each project. At the beginning of a project, they mostly had no knowledge of the industry or the necessary contacts. They were, though, able to overcome these liabilities within a short space of time. Teams that are already operational with the necessary competences play thus a greater 
role for the portfolio entrepreneur than for the serial entrepreneur in overcoming personal time constraints. The attraction of readily available complementary resources and the forging of already operational teams help portfolio entrepreneurs to overcome personal time constraints.

In the literature on entrepreneurship, reference is often made to the important role of the social network for the financing of entrepreneurial projects (Hsu 2003, 2004, 2005; McKelvie and Cedere 2001; Shane and Cable 2002). Both the case studies, however, show two different phenomena. Entrepreneur A has a relatively stable network for the financing of his projects. Entrepreneur B, on the other hand, worked with different financers in each firm. The results of the case studies show a positive connection between the number of implemented opportunities and the stability of the financial network. For portfolio entrepreneurs, financing is facilitated by continuous and ongoing relationships with existing investors. The number of ventures currently controlled by portfolio entrepreneurs increases the access to complementary resources (including financing). Serial entrepreneurs can benefit from signaling effects as (new) investors tend to judge start-up experience as a positive indicator of entrepreneurial qualities (Hsu 2003, 2004). In this sense, both serial and portfolio entrepreneurs enjoy a facilitated access to financing compared to novice entrepreneurs, even if the underlying mechanisms for the two types of habitual entrepreneurs are different. Serial and portfolio entrepreneurs build and develop social capital in a different way.

Proposition 4 Serial entrepreneurs are more willing to accept a learning situation both on the individual and the team level than portfolio entrepreneurs when launching a new venture.

Proposition 5 Financing of new ventures by habitual entrepreneurs is facilitated by different mechanisms for serial and portfolio entrepreneurs. To attract new investors, portfolio entrepreneurs rely more on continuous and ongoing financing relationships (i.e., previous and current investors) while serial entrepreneurs rely more strongly on signaling effects of entrepreneurship competences compared to novice entrepreneurs.

\section{Conclusion}

Due to the prevalence of the phenomenon of the habitual entrepreneur (Ronstadt 1986; Schollhammer 1991; Ucbasaran et al. 2003a), research on this group makes an important contribution to understanding entrepreneurship. The literature on the behavior and performance of habitual entrepreneurs began with anecdotes and assumptions. For some time now, these have been enhanced by the development and testing of concrete hypotheses. Our research contributes to the understanding of this phenomenon by answering "how" and "why" questions. We have focused on the early phases of the entrepreneurial process, such as the identification and implementation of opportunities based on habitual entrepreneurs' social capital. While confirming partially existing research, we developed new theoretical insights:

First, portfolio and serial entrepreneurs differ in how they identify and implement opportunities. These differences are influenced by differences in building and mobilizing 
social capital. The existence of business groups (a series of current ventures) creates a series of contingencies but also opportunities for portfolio entrepreneurs. Generally, portfolio entrepreneurs appear to have larger weak tie networks than serial entrepreneurs. Contingencies are time constraints (through commitment to multiple ventures) and network "maintenance" effects. Personal time constraints mean that portfolio entrepreneurs need to have a readily operative team for a new venture project requiring the attraction of high quality complementary resources. The choice of partners and their stakes need to be carefully balanced against the existing networks, thus trust relationships through strong relationships are perceived as a safeguard against harmful deceptions. While previous research considered the role of conflicting relationships outside the business group (Lechner and Leyronas 2009), our case is on inside relationships. Thus, non-appropriate choices of partners would trigger negative effects within the internal relationships of other existing ventures. On the positive side, ongoing financing relationships facilitate new venture financing. Portfolio entrepreneurs face more constraints because of their higher level of social capital reducing action autonomy and influencing also their risk attitude. Similarly, their level of risk avoidance should be higher.

Unlike portfolio entrepreneurs, serial entrepreneurs are free of these constraints while benefitting from entrepreneurial experience effects (compared to novice entrepreneurs), especially in terms of financing. This means that serial entrepreneurs can more easily break with the past and make more radical choices for setting up new ventures. However, through an increased indegree, portfolio entrepreneurs benefit from their reputation and business visibility in attracting new ideas and resources that subsequently can be transformed into viable resources for new ventures. We could speak of passive network building or social capital that can be mobilized. Serial entrepreneurs still need to proactively build networks by increasing the outdegree of contacts and creating new social capital. Being a serial entrepreneur has no direct and immediate social capital building effects.

Generally, the case studies advance our understanding of habitual entrepreneurship by uncovering in more depth how the effects of habitual entrepreneurship act on opportunity identification and exploitation. Early views of habitual entrepreneurs' advantages in carrying over project resources from previous ventures to subsequent ventures cannot be shared in such a simplistic fashion and are distinct for serial and portfolio entrepreneurs. It is rather a series of options created through previous ventures that facilitate new venture creation through social capital. Table 5 summarizes some of the main differences.

Table 5 Proposed differences between serial and portfolio entrepreneurs

\begin{tabular}{lll}
\hline & Serial entrepreneurs & Portfolio entrepreneurs \\
\hline Weak tie networks & Lower & Higher \\
Degree of change between ventures & High_radical & Moderate_continuous \\
Risk-friendliness & High & Moderate \\
Uncertainty avoidance & Low & Moderate \\
Financing & Signaling of entrepreneurial & Continuous financing \\
& competence & relationships \\
\hline
\end{tabular}


Second, the group of habitual entrepreneurs is often sub-divided into successful and non-successful entrepreneurs. The case studies have shown that this is not very realistic. Even long-term successful entrepreneurial activity is no guarantee for the success of a project. Entrepreneurial success would be better framed as a positive bottom line of a series of ventures with varying outcomes.

This research has some limitations. There might be some recall biases but the long-term relationship of one of the authors with the entrepreneurs should minimize the effects. Case study research draws conclusions from the cases to the theory. Hypothesis testing of the developed propositions should be a first indication for future research endeavors. Longitudinal and dynamic network analysis could investigate how and which elements of entrepreneurial networks are more proliferate for new venture creation.

Between the lines, it appears that portfolio entrepreneurs are more risk-averse or at least more risk alert than serial entrepreneurs. In this sense, it is not clear whether portfolio entrepreneurs have a lower willingness to take risks or whether they have a higher ability to see risks. Comparative studies could investigate the relationships between risk propensity and risk perception among different types of habitual entrepreneurs. A similar logic could apply to the learning motivation of habitual entrepreneurs, which can also be viewed as a form of ambiguity acceptance. Serial entrepreneurs appear to be more willing to accept the learning situation and ambiguity. In conclusion, we hope that our research will stimulate further research on habitual entrepreneurship.

\section{Methods}

The phenomenon of opportunity emergence in general and for different types of habitual entrepreneurs in particular is suffering from a theory deficit; a more in-depth exploration using qualitative methods is required (Suddaby et al. 2015). Case study analysis is a suitable choice for answering the "why" and "how" questions in unexplored areas and for deriving theoretical propositions to explain certain phenomena (Edmondson and McManus 2007; Yin 2003). These though have no claim to universal validity but refer to the case at hand (Schnell et al. 1999), drawing conclusions from the case to theory (Yin 2003). In this paper, four case studies of experienced habitual entrepreneurs are examined, following recommendations for comparative case studies (Eisenhardt 1989). The theoretical sampling consisted of two portfolio entrepreneurs and two serial entrepreneurs. Moreover, one serial and one portfolio entrepreneur were similar in that they had developed their business over a long period of time (about 20 years) while the other two had created multiple businesses over a shorter time span. Through this sampling, we wanted to increase the chances of gaining theoretical insights through the detection of uncommon phenomena (Eisenhardt and Graebner 2007). Two cases are considered as main cases (one serial and one portfolio entrepreneur) and the other two as complementing cases. While data collection in itself has been done equally for all cases, we focus on the two main cases A and B. The two complementary cases are used to validate the finding of the main cases or to refine the potentially emerging propositions without needing to represent the data in details. In this sense, we improve the case design by allowing for sufficient theoretical insight and respond to calls for reasonable data analysis and succinct case descriptions (Brown and Eisenhardt 1997). 
Semi-structured interview guidelines were used to collect the data of the four habitual entrepreneurs. Interviews were also carried out with people within their social environment, and their observations were supplemented and verified using secondary data, e.g., newspaper articles and information from the internet (following Eisenhardt 1989). Overall, 36 interviews were conducted over a 1-year period.

\section{Key concepts}

Social capital is created through investment in relationships that lead to valuable resources embedded in social networks that can be mobilized by an individual (Lin 1999). Within the existing literature, networks were described and measured in different ways (Wasserman and Faust 1994). Frequently used variables were the size of the network, the diversity of the actors (Zhao and Aram 1995), the number of connections of the central actor, centrality, which might not just only be measured by the number of connections but also by the meaning of the actor according to the access of resources (Hoang and Antoncic 2003), and a special position of an actor as a link between two networks, so-called bridging ties (Burt 1992).

To gain in-depth insights on habitual entrepreneurs, we developed an original approach for describing the business partner networks of the entrepreneur. Business partners were understood as those individuals who were actively involved in the execution, and without whom, the realization of the project would not have been possible. In addition, the partners who played an important supporting role but were replaceable in the end will be amassed. These business partners will be sorted by importance and displayed in a table. Each partner will be assigned a letter. If a partner was involved in several projects, this will be recognizable by the letter. In addition, every partner of entrepreneur A will be marked by an A index and the partners of entrepreneur B with a B index. Both tables will therefore show how often the entrepreneurs worked with which partners and how important these partners were for the execution. The differentiation of the networks and the network stability will become apparent. Alongside these networks, the number of business partners who held shares in the share capital of the company and the number of people who could have taken on this role will be considered. This will show how many alternatives the entrepreneur had for the execution of the project.

\section{Endnotes}

${ }^{1}$ We use the more neutral term of opportunity emergence or origin. There is an ongoing and unresolved debate about the discovery or creation of opportunities (see, e.g., Suddaby et al. 2015). Similar debates have animated marketing scholars for decades in terms of existing and latent needs (see, e.g., Slater and Narver 1998). Since we are mainly interested in opportunity emergence and how habitual entrepreneurs act upon them, and since this is an unexplored area, an a priori restriction to one perspective appears not to be practical. 


\section{Competing interests}

The authors declare that they have no competing interests.

\section{Author details}

${ }^{1}$ School of Economics and Management, Free University of Bolzano, Universitätsplatz 1 - piazza Università, 1, Bozen-Bolzano, Italy. ${ }^{2}$ Max-Planck-Innovation $\mathrm{GmbH}$, Munich, Germany. ${ }^{3}$ Innovation and Technology Management, University of Regensburg, Regensburg, Germany.

Received: 12 May 2016 Accepted: 23 September 2016

Published online: 30 September 2016

\section{References}

Aldrich, HE, \& Martinez, MA. (2001). Many are called, but few are chosen: An evolutionary perspective for the study of entrepreneurship. Entrepreneurship Theory and Practice, 25(4), 41-56.

Aldrich, H, \& Zimmer, C (1986). Entrepreneurship through social networks. In R. Smilor \& D. Sexton (Eds.), The art and science of entrepreneurship (pp. 3-23). New York: Ballinger.

Alsos, G, \& Carter, S (2003). Portfolio entrepreneurship: resource transfer and performance consequences. Presented at Babson Kauffman Entrepreneurship Research Conference 2003, Babson College, MA

Alsos, G, \& Kaikkonen, V (2004). Opportunity recognition and prior knowledge: a study of experienced entrepreneurs. Presented at the 13th Nordic Conference on Small Business Research, 10-12 Juni, in Tromsø, Norway

Alsos, G, \& Kolvereid, L (1998). The business gestation process of novice, serial and parallel business founders. Entrepreneurship Theory and Practice, 22(4), 101-114

Alvarez, SA, Young, SL, \& Woolley, JL (2015). Opportunities and institutions: a co-creation story of the king crab industry. Journal of Business Venturing, 30(1), 95-112.

Amaral, AM, Baptista, R, \& Lima, F (2009). Becoming an ex-entrepreneur: firm performance and the sell-out or dissolution decision. In D. Smallbone, H. Landström, \& D. Jones-Evans (Eds.), Entrepreneurship and growth in local, regional and national economies: Frontiers in European entrepreneurship research (pp. 157-183). Cheltenham: Edward Elgar.

Ardichvili, A, Cardozo, R, \& Ray, S (2003). A theory of entrepreneurial opportunity identification and development. Journal of Business Venturing, 18(1), 105-123.

Baker, T, \& Nelson, R (2005). Creating something from nothing: resource construction through entrepreneurial bricolage. Administrative Science Quarterly, 50(3), 329-366.

Baron, R (2006). Opportunity recognition as pattern recognition: how entrepreneurs "connect the dots" to identify new business opportunities. Academy of Management Perspectives, 20(1), 104-119.

Baum, J, Calabrese, T, \& Silverman, B (2000). Don't go it alone: alliance network composition and startups' performance in Canadian biotechnology. Strategic Management. Special Issue: Strategic Networks, 21(3), 267-294.

Birley, S, \& Westhead, P (1993). A comparison of new businesses established by "novice" and "habitual" founders in Great Britain. International Small Business Journal, 12(1), 38-60.

Brown, SL, \& Eisenhardt, KM (1997). The art of continuous change: linking complexity theory and time-paced evolution in relentlessly shifting organizations. Administrative Science Quarterly, 1-34

Brüderl, J, \& Preisendörfer, R (1998). Network support and the success of newly founded businesses. Small Business Economics, 10(3), 213-225

Burt, R (1992). Structural holes. Cambridge: Harvard University Press.

Carter, S, \& Ram, M (2003). Reassessing portfolio entrepreneurship. Small Business Economics, 21(4), 371-380.

De Koning, A, \& Muzyka, D (1996). The convergence of good ideas: how do serial entrepreneurs recognize innovative business ideas? Working paper in the INSEAD Working Paper Series. INSEAD, Fontainebleau, France

Donckels, R, Dupont, B, \& Michel, P (1987). Multiple business starters. Who? Why? What? Journal of Small Business and Entrepreneurship, 5(1), 48-63.

Edmondson, AC, \& McManus, SE (2007). Methodological fit in management field research. Academy of Management Review, 32(4), 1246-1264

Eisenhardt, K (1989). Building theories from case study research. Academy of Management Review, 14(4), 532-550.

Eisenhardt, KM, \& Graebner, ME (2007). Theory building from cases: opportunities and challenges. Academy of Management Journal, 50(1), 25-32.

Gibb, A, \& Ritchie, J (1982). Understanding the process of starting small businesses. European Small Business Journal, $1(1), 26-45$.

Granovetter, M (1973). The strength of weak ties. American Journal of Sociology, 78(6), 1360-1380.

Granovetter, M (1974). Getting a job: a study of contacts and careers. Boston: Harvard University Press.

Granovetter, M (1995). Getting a job: a study of contacts and careers (2nd ed.). Chicago: University of Chicago Press.

Hall, P (1995). Habitual owners of small businesses. In F. Chittenden, M. Robertson, \& I. Marshall (Eds.), Small firms: Partnerships for growth (pp. 217-230). London: Paul Chapman Publishing.

Harrison, J, Hitt, M, Hoskisson, R, \& Ireland, R (2001). Resource complementarity in business combinations: extending the logic to organizational alliances. Journal of Management, 27(6), 679-690.

Hart, M, Stevenson, H, \& Dial, J (1995). Entrepreneurship: a definition revisited. In J. Bygrave, B. Bird, B. Birley, N. Churchill, M. Hay, R. Keeley, \& W. Wetzel (Eds.), Frontiers of entrepreneurship research. Wellesley: Babson College.

Hoang, H, \& Antoncic, B (2003). Network-based research in entrepreneurship: a critical review. Journal of Business Venturing, 18(2), 165-187.

Hsu, D (2003). Serial entrepreneurs, venture capital funding, and social network substitution. Working paper.

Hsu, D (2004). What do entrepreneurs pay for venture capital affiliation? The Journal of Finance, 59(4), 1805-1844

Hsu, D (2005). Experienced entrepreneurial founders, social capital, and venture capital funding. Working paper. The Wharton School, University of Pennsylvania, Philadelphia, PA 
lacobucci, D (2002). Explaining business groups started by habitual entrepreneurs in the Italian manufacturing sector. Entrepreneurship \& Regional Development, 14(1), 31-47.

lacobucci, D, \& Rosa, P (2004). Habitual entrepreneurs, entrepreneurial team development and business group formation. Presented at RENT XVIII-Managing Complexity and Change in SMEs, 24-26. November, Copenhagen

lacobucci, D, \& Rosa, P (2005). Growth, diversification, and business group formation in entrepreneurial firms. Small Business Economics, 25(1), 65-82.

lacobucci, D, \& Rosa, P (2010). The growth of business groups by habitual entrepreneurs: the role of entrepreneurial teams. Entrepreneurship Theory and Practice, 34(2), 351-377.

Johannisson, B (1987). Anarchists and organizers: entrepreneurs in a network perspective. International Studies of Management and Organization, 17(1), 49-63.

Kirschenhofer, F, \& Lechner, C (2012). Performance drivers of serial entrepreneurs: Entrepreneurial and team experience. International Journal of Entrepreneurial Behavior \& Research, 18(3), 305-329.

Krackhardt, D (1992). The strength of strong ties: the importance of philos in organizations. In N. Nohria \& R. Eccles (Eds.), Networks and organizations (pp. 216-239). Boston: Harvard Business School Press.

Lamont, L (1972). What entrepreneurs learn from experience. Journal of Small Business Management, 10(3), 36-41.

Larson, A (1991). Partner networks: leveraging external ties to improve entrepreneurial performance. Journal of Business Venturing, 6(3), 173-188.

Lechner, C (2003). Unternehmensnetzwerke: Wachstumsfaktor für Gründer. In M. Dowling \& H. Drumm (Eds.), Gründungsmanagement (pp. 305-315). Berlin: Springer.

Lechner, C, \& Dowling, M (2003). Firm networks: external relationships as sources for the growth and competitiveness of entrepreneurial firms. Entrepreneurship \& Regional Development, 15(1), 1-26.

Lechner, C, \& Kirschenhofer, F (2004). "Management by coincidence"—how entrepreneurs develop their business. In M. Dowling, J. Schmude, \& D. zu Knyphausen-Aufsess (Eds.), Advances in Interdisciplinary European Entrepreneurship Research, Vol. II, Nr. 4 (pp. 43-76). Münster: LIT Verlag.

Lechner, C, \& Leyronas, C (2009). Small business group formation as an entrepreneurial development model. Entrepreneurship Theory and Practice, 33(3), 645-667.

Lechner, C, Dowling, M, \& Welpe, I (2006). Firm networks and firm development: the role of the relational mix. Journal of Business Venturing, 21(4), 514-540.

Lin, N (1999). Building a network theory of social capital. Connections, 22(1), 28-51.

Lipparini, A., \& Sobrero, M. (1997). Coordinating multi-firm innovative processes: entrepreneur as catalyst in small-firm networks. In M. Ebers (Ed.), The formation of inter-organizational networks (pp. 199-219). Oxford: Oxford University Press.

MacMillan, I (1986). To really learn about entrepreneurship, let's study habitual entrepreneurs. Journal of Business Venturing, 1(3), 241-243.

Mathias, BD, Williams, DW, \& Smith, AR (2015). Entrepreneurial inception: the role of imprinting in entrepreneurial action. Journal of Business Venturing, 30(1), 11-28.

McEvily, B, \& Zaheer, A (1999). Bridging ties: a source of firm heterogeneity in competitive capabilities. Strategic Management Journal, 20(12), 1133-1156.

McGrath, R (1996). Options and the entrepreneur: toward a strategic theory of entrepreneurial wealth creation. In Academy of Management Proceedings, Entrepreneurship Division (pp. 101-105).

McGrath, R, \& MacMillan, I (2000). The entrepreneurial mindset. Boston: Harvard Business School Press.

McKelvie, A, \& Cedere, A (2001). Network pollination: habitual entrepreneurship and incubators. In J. Bygrave, E. Autio, C. Brush, P. Davidsson, P. Green, P. Reynolds, \& H. Sapienza (Eds.), Frontiers of entrepreneurship research. Wellesley: Babson College.

McMullen, J, \& Shepherd, D (2006). Entrepreneurial action and the role of uncertainty in the theory of the entrepreneur. Academy of Management Review, 31(1), 132-152.

Roininen, S, \& Ylinenpää, H (2010). New ventures' entry strategies a comparison of academic and non-academic business startups. Entrepreneurship and the Creation of Small Firms: Empirical Studies of New Ventures.

Ronstadt, R (1986). Exit, stage left: why entrepreneurs end their entrepreneurial careers before retirement. Journal of Business Venturing, 1(3), 323-338.

Rosa, P, \& Scott, M (1999). The prevalence of multiple owners and directors in the SME sector: implications for our understanding of start-up and growth. Entrepreneurship \& Regional Development, 11(1), 21-37.

Sarasvathy, S, \& Menon, A (2004). Failing firms and successful entrepreneurs: serial entrepreneurship as a temporal portfolio. Working paper under review at Management Science.

Schnell, R, Hill, P, \& Esser, E (1999). Methoden der empirischen Sozialforschung. München: Oldenburg Verlag.

Schollhammer, H (1991). Incidence and determinants of multiple entrepreneurship. In N. Churchill, W. Bygrave, J. Covin, D. Sexton, D. Slevin, K. Vesper, \& W. Wetzel (Eds.), Frontiers of entrepreneurship research (pp. 11-24). Wellesley: Babson College.

Scott, M, \& Rosa, P (1996). Has firm level analysis reached its limits? Time for a rethink. International Small Business Journal, 14(4), 81-89.

Shane, S, \& Cable, D (2002). Network ties, reputation, and the financing of new ventures. Management Science, 48(3), 364-381.

Shane, S, \& Venkataraman, S (2000). The promise of entrepreneurship as a field of research. Academy of Management Review, 25(1), 217-226

Slater, SF, \& Narver, JC (1998). Research notes and communications customer-led and market-oriented: Let's not confuse the two. Strategic management journal, 19(10), 1001-1006.

Stam, W (2010). Industry event participation and network brokerage among entrepreneurial ventures. Journal of Management Studies, 47(4), 625-653.

Starr, J, \& Bygrave, W (1991). The assets and liabilities of prior start-up experience: An exploratory study of multiple venture entrepreneurs. In N. Churchill, W. Bygrave, J. Covin, D. Sexton, D. Slevin, K. Vesper, \& W. Wetzel (Eds.) Frontiers of entrepreneurship research (pp. 213-227). Wellesley: Babson College. 
Starr, J, \& MacMillan, I (1990). Resource cooptation via social contracting: resource. acquisition strategies for new ventures. Strategic Management Journal, 11(4), 79-92.

Stinchcombe, A (1965). Social structure and organizations. In J. March (Ed.), Handbook of organizations (pp. 142-193). Chicago: Rand McNally.

Suddaby, R, Bruton, GD, \& Si, SX (2015). Entrepreneurship through a qualitative lens: insights on the construction and/ or discovery of entrepreneurial opportunity. Journal of Business Venturing, 30(1), 1-10.

Timmons, J, \& Spinelli, S (2003). New venture creation - entrepreneurship for the 21st century. International edition (6th ed. ). Boston: McGraw-Hill.

Ucbasaran, D, Wright, M, \& Westhead, P (2003). A longitudinal study of habitual entrepreneurs: starters and acquirers. Entrepreneurship \& Regional Development, 15(3), 207-228.

Ucbasaran, D, Westhead, P, Wright, M, \& Binks, M (2003). Does entrepreneurial experience influence opportunity identification? The Journal of Private Equity, 7(1), 7-14.

Ucbasaran, D, Westhead, P, \& Wright, M (2006). Habitual entrepreneurs. Cheltenham: Edward Elgar.

Vaghely, I, \& Julien, P (2010). Are opportunities recognized or constructed? An information perspective on entrepreneurial opportunity identification. Journal of Business Venturing, 25(1), 73-86.

Wasserman, S, \& Faust, K (1994). Social network analysis: methods and applications. New York: Cambridge University Press.

Westhead, P, \& Wright, M (1998). Novice, portfolio, and serial entrepreneurs: are they different? Journal of Business Venturing, 13(3), 173-204.

Westhead, P, \& Wright, M (1999). Contributors of novice, portfolio and serial founders located in rural and urban areas. Regional Studies, 33(2), 157-173.

Westhead, P, Ucbasaran, D, \& Wright, M (2003). Differences between private firms owned by novice, serial and portfolio entrepreneurs: implications for policy makers and practitioners. Regional Studies, 37(2), 187-200.

Westhead, P, Ucbasaran, D, Wright, M (2004). Experience and cognition: do novice, serial and portfolio entrepreneurs differ? Presented at the 13th Nordic Conference on small business research 2004

Wiklund, J, \& Shepherd, D (2008). Portfolio entrepreneurship: habitual and novice founders, new entry, and mode of organizing. Entrepreneurship Theory and Practice, 32(4), 701-725.

Wisnieski, J, \& Dowling, M (1997). Strategic alliances in new ventures: does governance structure affect new venture performance? Paper presented at the Annual Babson College-Kaufmann Foundation Entrepreneurship Conference (BKERC), Babson College, Wellesley, MA

Witt, P (2004). Entrepreneurs' networks and the success of start-ups. Entrepreneurship \& Regional Development, 16(5), $391-412$.

Wright, M, Robbie, K, \& Ennew, C (1997). Serial entrepreneurs. British Journal of Management, 8(3), 251-268.

Yin, R (2003). Case study research (3rd ed.). Thousand Oaks: Sage Publications.

Zhao, L., \& Aram, JD (1995). Networking and growth of young technology-intensive ventures in China. Journal of business venturing, 10(5), 349-370.

\section{Submit your manuscript to a SpringerOpen ${ }^{\circ}$ journal and benefit from:}

- Convenient online submission

- Rigorous peer review

- Immediate publication on acceptance

- Open access: articles freely available online

- High visibility within the field

- Retaining the copyright to your article 